\section{AKADEMOS}

Órgano de difusión de la Red Docencia-Investigación

\section{ISSN: $1995-4743$}

Año 14 Vol. 1, n. 34 Enero-Junio 2020

AKADEMOS es una revista semestral. De amplio espacio editorial, para la publicación de trabajos inéditos de investigación, artículos de análisis, reseñas y opinión, en los distintos tópicos de las ciencias, la tecnología, las artes y la cultura.

\title{
Homenaje a Roque Dalton en el LXXXV aniversario de su nacimiento y XLV aniversario de su asesinato
}

Carmen González Huguet

Licenciada en Letras, Docente Investigadora

Escuela de Ciencias de la Comunicación

carmengonzalezh@yahoo.com

Fecha de recepción 04/05/2020 • Fecha de aceptación 29/05/2020

\section{Parte 1: Contexto y datos biográficos}

\subsection{Contexto histórico}

Arturo Araujo, presidente de El Salvador, fue derrocado por un golpe militar el 2 de diciembre de 1931. A raíz de este hecho, subió al poder el vicepresidente, Maximiliano Hernández Martínez (1882-1966), quien gobernó defacto de 1931 a 1944. Las inhumanas condiciones de vida de los campesinos, en su mayoría indígenas sin tierras, facilitaron que se hicieran eco de las ideas propagadas por los miembros del Partido Comunista Salvadoreño. Sin embargo, hasta dónde dicho "indoctrinamiento" fue real, y hasta dónde fue producto de la imaginación de los dirigentes de esta agrupación, o amplificado adrede por los simpatizantes de la derecha o de la izquierda deseosos, cada uno, de llevar agua a su molino, sigue siendo motivo de especulación.

El autor estadounidense Thomas R. Anderson $^{1}$ ha sido una de las fuentes que han cuestionado las cifras de bajas que se han

1 Anderson, Thomas R. (2001). El Salvador, 1932. S. S., DPI. 3a edición en español. ISBN 99923-0-059-0. 
manejado en relación con las explosiones de violencia que ocurrieron en 1932. Es difícil separar los hechos de las percepciones. No obstante, diferentes autores ${ }^{2}$ concuer- $^{-}$ dan en que el 22 de enero de ese año una insurrección campesina estalló en la zona montañosa al norte de los departamentos de Sonsonate y Ahuachapán. Armados con machetes e instrumentos de labranza, los rebeldes se apoderaron de las poblaciones de Juayúa, Izalco, Nahuizalco y Tacuba. También atacaron los cuarteles militares de Ahuachapán, Sonsonate y Santa Tecla, sin conseguir apoderarse de dichas plazas.

En un primer momento, el general Hernández Martínez se preocupó de justificar su llegada al poder, y sobre todo, de mantener la estabilidad y la seguridad nacionales ${ }^{3}$ aunque el costo fuera muy elevado en vidas y daños materiales. La justificación era muy importante, porque los Estados Unidos habían intervenido en numerosas ocasiones en diferentes naciones latinoamericanas con resultados desastrosos para dichos estados ${ }^{4}$. Como demuestra la serie de telegramas enviados por William J. McCafferty, en ese momento Encargado de Asuntos Diplomáticos de los Estados Unidos de América en San Salvador, al Departamento de Estado, tanto los EUA como Gran Bretaña enviaron buques a los puertos salvadoreños con regimientos de marines listos para desembarcar con la intención de salvaguardar las vidas e intereses económicos de los ciudadanos estadounidenses y británicos residentes en El Salvador 5 . Cumplir con dicho objetivo explica, si bien no justifica, la desproporcionada y dolosa represión que impulsó el gobierno militar para "pacificar" la zona donde ocurrió la revuelta.

Las distintas fuentes no se ponen de acuerdo ni siquiera con respecto a las cifras de los muertos causados por una y otra parte. Thomas R. Anderson ${ }^{6}$ calcula que los rebeldes mataron durante la insurrección a unas cien personas en total; mientras que las fuerzas gubernamentales pudieron haber asesinado a unas diez mil personas, insurrectas o no. Porque en lo que también las fuentes coinciden es en que muchos de los campesinos fusilados no habían participado en la revuelta. En todo caso, Anderson

2 Fuentes, entre otras: Dalton, Roque (1993). 0. c., Jeffrey L. y Lauria-Santiago, Aldo (s/f). 1932, Rebelión en la oscuridad. S. S., Museo de la Palabra y la Imagen. Sin ISBN, y especialmente Anderson, Thomas R. (2001). 0. c.

3 Discurso del general Maximiliano Hernández Martínez a la Asamblea Legislativa, publicado en Diario Oficial, Tomo 112, №. 28, 4 de febrero de 1932. Hay versión digital en: www.diariooficial.gob.sv/diarios/1932/1932-1T/1932-1T_Parte6.pdf, consultado el 14 de septiembre de 2016.

4 Solo algunas: México en 1846, Nicaragua 1854, Cuba 1898 y 1901, Panamá 1903, República Dominicana 1906 y un largo etcétera. Ver: http:// www.voltairenet.org/article125406.html, consultado el 14 de septiembre de 2016.

5 Telegramas cruzados San Salvador y Washington. Mensajes del encargado de la Oficina de los intereses estadounidenses en San Salvador y de varios funcionarios del Departamento de Estado de los Estados Unidos de América entre el 21 de enero y el 1 de febrero de 1932. Traducción literal de Carmen González Huguet, revisada por Rafael Lara Martínez, Gloria González-Martin y María Elena Vidales de Bottlick. Documentación de acuerdo a los originales conservados en los archivos del Departamento de Estado proporcionada por: Carlos Cañas Dinarte, publicados en Revista de la Escuela de Ciencias de la Comunicación, Universidad “Dr. José Matías Delgado", Año 8, Vol. 8, No. 1, Correlativo 15. Enero-junio 2007.

6 Anderson, Thomas (2001). 0. c. Pág. 251 y ss. 
atribuye a la represión más del 90\% de las muertes. En un país golpeado por la crisis económica producto de la debacle de Wall Street de 1929, la matanza, que según la misma fuente eliminó al 0.7 por ciento de la población global de El Salvador, tuvo un impacto profundo y perdurable. Entre otras cosas, se convirtió en lo que algunos han dado en llamar una "cicatriz en la memoria".

Después de la matanza, Martínez se dedicó a implementar medidas que paliaran la crisis económica. Para ello, decretó una moratoria de la deuda bancaria para evitar el juicio hipotecario y las ventas forzadas de las propiedades cafetaleras. Al respecto, Cardenal explica: "Antes de la depresión, una de las obligaciones principales del Estado era preservar y defender los intereses de los cafetaleros. Después de la depresión, el Estado continuó defendiendo los mismos intereses, pero carecía de recursos... Mientras los administradores de la oligarquía liberal vacilaban ante las demandas de las asociaciones de los cafetaleros, estos intentaron bajar sus costos de producción. Esto implicaba reducir los salarios y despedir a los trabajadores no necesarios. Al trasladar a los trabajadores la carga del ajuste, los cafetaleros provocaron protestas violentas, en particular en la zona occidental de El Salvador... Las economias centroamericanas se recuperaron gracias a medidas audaces como el incumplimiento del pago de la deuda, lo cual liberó recursos. En Guatemala,
El Salvador y Costa Rica, donde el incumplimiento fue mayor, la recuperación fue más rápida. En segundo lugar, los gobiernos generaron empleo en las áreas rurales construyendo carreteras, con lo cual, además, expandieron esta infraestructura. En efecto, en la década de 1930, la construcción de carreteras fue la actividad que se expandió más rápido, pues requería de una mano de obra intensiva y su costo era bajo... La tercera medida, la devaluación, fue la más beneficiosa para los cafetaleros. Finalmente, todos, excepto Costa Rica, implantaron una disciplina laboral rígida..."

Pese a sus posiciones abiertamente anticomunistas, el general Martínez tuvo que esperar para que el gobierno de los Estados Unidos reconociera su gobierno. Y a ello no contribuyeron sus declaradas simpatías por el nazismo y el fascismo. De hecho, en 1938 Martínez nombró director de la Escuela Militar a Eberhard Bohnstedt (1886-1957) ${ }^{8}$, en aquella época coronel de la Wehrmacht, y además entabló relaciones diplomáticas con el dictador Francisco Franco, jefe del estado español a partir de 1939. Con todo, cuando los Estados Unidos entraron en la Segunda Guerra Mundial, a partir del 7 de diciembre de 1941, el gobierno de Martínez declaró la guerra a las naciones del Eje $\mathrm{e}^{9}$ y no titubeó en deportar a los ciudadanos de origen japonés, italiano y alemán, quienes fueron enviados para ser recluidos en campos

7 Cardenal, Rodolfo (1996). 0. c. Pág. 343 y s.

8 Loveman, Brian y Davies, Jr, Thomas M. (1997). The Politics of Antipolitics: The Military in Latin America. Lanham,United Kingdom, SR Books. Publicado por primera vez en 1978, y luego reeditado en 1989 por la Universidad de Nebraska, EUA. Verademás Williams, Phillip J. y Walter, Knut (1997). Militarization and Demilitarization in EI Salvador's Transition to Democracy. University of Pittsburg Press, Pensilvania, EUA.

9 D. 0.281, tomo 131, Decreto Legislativo número 93, del 15 de diciembre de 1941: el gobierno de El Salvador declaró la guerra a Alemania y a Italia. Previamente, el 8 de diciembre de ese año, mediante el Decreto Legislativo número 90, le había declarado la guerra a Japón. 
de concentración situados en territorio estadounidense. En esto Martínez no actuó de modo distinto a los demás gobernantes del área, quienes declararon la guerra a Japón a raíz del ataque a Pearl Harbor, situación que se explica por sí sola si tomamos en cuenta que el año anterior se había firmado en Washington un acuerdo interamericano del café, por el cual se otorgaron cuotas en el mercado estadounidense. Este acuerdo tuvo la consecuencia de elevar el precio del grano, lo cual aumentó el valor de las exportaciones y el poder económico y político de los caficultores en El Salvador.

Sobre el efecto de este conflicto, Cardenal señala: "El desorden del mercado internacional causado por la Segunda Guerra Mundial puso en aprietos serios a las economías centroamericanas, pero solo momentáneamente. Dada su ubicación geográfica, la región adquirió una importancia estratégica enorme para Estados Unidos. A cambio de permitir el establecimiento de bases, los cinco países recibieron un flujo constante de ayuda económica y militar. Washington envió misiones militares a la región, excepto a Honduras, para reemplazar la influencia alemana e italiana en los ejércitos. El suministro de armas no contribuyo al desarrollo económico, pero sí el financiamiento de la carretera Panamericana, ${ }^{\prime \prime 10}$.

El 1 de septiembre de 1939, los ejércitos de la Alemania nazi invadieron Polonia, cuya caída fue acelerada por el ataque de la Unión Soviética a partir del 17 de septiembre, sin que Francia y el Reino Unido hiciesen nada por ayudar a la nación polaca, cuyo ejército terminó de rendirse el 6 de octubre de ese mismo año. Entre tanto, en El Salvador la dictadura del general Maximiliano Hernández Martínez se prolongó hasta 1944. El 2 de abril, Domingo de Ramos, estalló una rebelión militar rápidamente abortada por el régimen. A pesar de la dura represión, la sociedad civil se aglutinó en torno al movimiento estudiantil, y tras una Huelga de Brazos Caídos, el 9 de mayo el general se vio obligado a depositar el poder en la persona del general Andrés Ignacio Menéndez y salió del país. Sin embargo, el líder de la oposición a Martínez, el doctor Arturo Romero, no gozaba de la confianza ni de los militares ni de los terratenientes, ya que su plataforma tenía un tinte reformista con el que no comulgaban. El 20 de octubre de 1944 un golpe de estado derrocó al sucesor de Martínez y elevó al poder al coronel Osmín Aguirre y Salinas, a la sazón director de la Policía Nacional. Aguirre desató una represión que desarticuló a la oposición y obligó a muchos simpatizantes de Romero a refugiarse en Guatemala, donde había caído la oscura tiranía del general Jorge Ubico y se iniciaba la etapa cuando Juan José Arévalo y Jacobo Árbenz dominarían la escena política.

Hubo un intento de invasión por parte de los exilados, que planeaban derrocar a Osmín Aguirre, pero estas acciones fracasaron. Las elecciones se adelantaron y en 1945 subió al poder el general Salvador Castaneda Castro. Tanto durante el gobierno de Osmín 
Aguirre como en el de Castaneda Castro los sindicatos fueron reprimidos y forzados a actuar clandestinamente. A su vez, Castaneda Castro fue derrocado por otro golpe de estado que estalló en diciembre de 1948. "La propaganda oficial presentó el golpe como "la revolución de $1948^{\prime \prime l l}$. El poder fue asumido por una junta cívico militar que "...se comprometió a establecer un sistema democrático, garantizado por reformas institucionales y la elevación del nivel de vida de la población. A continuación, eliminó lo que quedaba del régimen anterior, dando de baja a generales y coroneles más antiguos y procesando y encarcelando a los colaboradores de Aguirre y Castaneda. Los intelectuales y profesionales, así como los grupos populares urbanos, apoyaron a la junta a partir de sus primeras actuaciones... El coronel [Óscar] Osorio resultó electo a principios de 1950 y en octubre se promulgó la nueva constitución". ${ }^{12}$

Después de la Segunda Guerra Mundial, los buenos precios del café permitieron al gobierno de Óscar Osorio impulsar decididamente la inversión en infraestructura: Se construyó la primera presa hidroeléctrica, llamada "5 de noviembre", con la que dio inicio la electrificación a gran escala y despegó la industria manufacturera. También se construyó el moderno puerto de Acajutla, la carretera del Litoral, otras carreteras secundarias y se impulsó la urbanización de las principales ciudades del país, mediante la creación del Instituto de Vivienda Urba- na, IVU, el cual gestionó la construcción de numerosas colonias habitacionales, como la Centroamérica y la Libertad, a inmediaciones del nuevo campus de la Universidad de El Salvador, al final de la 25 avenida Norte, en la capital. Cardenal afirma: "En estos primeros años de la década de 1950, el Estado se convirtió en el promotor del desarrollo. El coronel Osorio derogó las leyes anti-industriales heredadas de la dictadura y las reemplazó por otras que otorgaban incentivos a la inversión en sectores nuevos..." "'s. Sin embargo, este desarrollo material no llegó a todos. Cardenal señala que "... las relaciones del gobierno del coronel Osorio con las organizaciones obreras fueron fuctuantes. El Comité de Reorganización Obrero Sindical... fue declarado ilegal y sus dirigentes... expulsados del país en 1951... al año siguiente se aprobó la "Ley de defensa del orden democrático y constitucional" destinada a controlar la organización popular independiente". ${ }^{14}$

Osorio impuso la candidatura oficial del coronel José María Lemus para sucederlo en la presidencia. Sin embargo, el gobierno de Lemus coincidió con la declinación de los precios del café, con lo que la situación económica del país se deterioró. Además, los gobiernos de Juan José Arévalo y de Jacobo Árbenz en Guatemala, entre 1944 y 1954, así como el triunfo de la revolución cubana en 1959, agudizaron la percepción del "peligro comunista", un fenómeno social que la

11 Cardenal, Rodolfo (1996). 0. c. Pág. 387.

12 Cardenal, Rodolfo (1996). 0. c. Pág. 387.

13 Cardenal, Rodolfo (1996). 0. c. Pág. 387 y ss.

14 Cardenal, Rodolfo (1996). 0. c. Pág. 388. 
clase dirigente veía con mucho temor. Afirma Cardenal: "En 1959, después del triunfo de Castro en Cuba, la oligarquía pidió medidas más drásticas, pues Lemus habia derogado la "Ley de defensa de la democracia" y permitió la organización sindical independiente. En este contexto, el Partido Comunista dio sus primeros pasos hacia la lucha armada al formar "grupos de acción" en los sindicatos y en la Universidad de El Salvador". En ese contexto, "...los estudiantes y los trabajadores se adueñaron de las calles. Las manifestaciones estudiantiles fueron ametralladas. Las cárceles se llenaron con los presos políticos. El ejército invadió la Universidad de El Salvador... los políticos de oposición, incluido el exministro de relaciones exteriores Roberto Canessa... fueron arrestados y torturados. Hasta la prensa estadounidense comentó que Lemus habia ido demasiado lejos. El 26 de octubre de 1960 este fue derrocado por el coronel Osorio y sus amigos". ${ }^{15}$

Lemus fue sustituido primero por una junta integrada por tres profesionales de pensamiento liberal: Fabio Castillo, René Fortín Magaña y Ricardo Falla Cáceres, y por tres militares jóvenes: el mayor Rubén Alonso Rosales, el coronel Julio César Yánez Urías ${ }^{16}$ y el teniente coronel Miguel Ángel Castillo. Sin embargo, como señala Cardenal, los planes de esta junta encontraron resistencia en diferentes sectores sociales. En concreto, este autor señala tres instancias opuestas a la primera junta: los militares afines a Osorio, que deseaban controlar y manipular a la junta, los miembros de la llamada oligarquía y la embajada de Estados Unidos, que creía, con temor, que algunos miembros de la junta simpatizaban con la revolución cubana. El 25 de enero de 1961 una segunda junta derrocó a la anterior. Estaba integrada por el coronel Aníbal Portillo, el teniente coronel Julio Adalberto Rivera y los civiles Feliciano Avelar, José Francisco Valiente y Antonio Rodríguez Porth.

Mientras todo esto sucedía en El Salvador, el mundo era escenario de la llamada Guerra Fría. Para los Estados Unidos era fundamental contar con gobiernos anticomunistas en lo que ya consideraba "su patio trasero" El 17 de abril de 1961 se produjo la llamada invasión de Bahía de Cochinos o Playa Girón. Entretanto, después de dos juntas militares, 25 de enero de 1962 asumió la presidencia provisional de El Salvador el abogado Eusebio Rodolfo Cordón Cea (1899-1966) ${ }^{17}$. Ese mismo año, el general Julio Adalberto Rivera (1921-1973) ganó las elecciones como candidato único. De él dice Cardenal: "Resultó ser el socio perfecto de la Alianza para el progreso. Era vigoroso, encantador y carismático. Una versión latina de Kennedy y en uniforme militar. Se paseaba por el campo en motocicleta, inaugurando escuelas y proyectos de irrigación. El coronel Rivera, bajo la égida de la Alianza para el progreso, continuó con las reformas, por lo menos hasta 1964. En 1963 promulgó el código de trabajo y una nueva ley electoral que

15 Cardenal, Rodolfo (1996). 0. c. Pág. 389.

16 Este militar estuvo casado con Floritchica Valladares, la única hija de la escritora Matilde Elena López (1919-2010).

17 Cardenal, Rodolfo (1996). 0. c. Pág. 390. 
aseguraba a la oposición una representación proporcional en la asamblea legislativa. Entre 1964 y 1968, los partidos opositores, en especial el Demócrata Cristiano, fueron aumentando su presencia en la asamblea legislativa". ${ }^{18}$

"En 1966 la democracia cristiana ganó un tercio de las alcaldias del país. Cuando el gobierno, presionado por Washington, elevó el salario minimo de los trabajadores agrícolas, haciéndolo llegar a 90 centavos de dólar en $1965^{19}$, los terratenientes respondieron impidiendo que aquellos sembraran en las pequeñas parcelas que siempre habian utilizado para cultivos de subsistencia, y dejando de servir el almuerzo tradicional de una tortilla y un puñado de frijoles. Además, protestaron ante el embajador estadounidense e incluso un ex funcionario del Departamento de Estado visitó San Salvador para exigir al representante diplomático del país pedir al presidente salvadoreño suprimir las reformas". Como bien señala Cardenal, a pesar de dichas reformas, la estructura económica del país no solo quedó intacta, sino que, gracias a la ayuda de la Alianza para el progreso, los grupos dominantes multiplicaron su riqueza gracias al impulso dado a empresas comerciales e industriales. La misma fuente indica que "la inversión estadounidense aumentó en la década de 1960, llegando a representar el 65\% 45 millones de dólares) de toda la inversión extranjera de 1967... En la década de 1960, Estados Unidos invirtió en El Salvador la mitad de todo lo que habia invertido desde 1900 hasta entonces y 44 multinacionales abrieron oficinas en el pais. Washington anunció orgullosamente que El Salvador era el modelo de lo que la Alianza para el progreso podía hacer"20. Sin embargo, los beneficios de esa bonanza económica no llegaban a la totalidad de la población. La mayor parte de los salvadoreños, residentes en el área rural y dedicados a la agricultura, subsistían con menos de un dólar diario. ${ }^{21}$ Estas condiciones han mejorado, pero todavía en la actualidad una gran parte de la población salvadoreña subsiste a duras penas bajo la línea de pobreza. Una publicación de 2014 del PNUD menciona: "En El Salvador, 4 de cada 10 personas aún sobreviven con ingresos entre los $\$ 4$ y $\$ 10$ dólares diarios que, aunque los exenta [exime] de un nivel de pobreza extrema, los coloca en el indice de mayor vulnerabilidad, según el último informe sobre Desarrollo Humano 2014, revelado por el Programa de las Naciones Unidas para el Desarrollo (PNUD). En el año 2000, sólo el 34. 9\% de la población salvadoreña era parte de éste rango, sin embargo, en el 2012, este mismo grupo aumentó a 41.4\% (un aumento del 6.5\%). Sin embargo, según el análisis del PNUD, en este mismo periodo de tiempo tam-

18 Cardenal, Rodolfo (1996). 0. c. Pág. 390.

19 Noventa centavos de dólar al día. El salario anterior era de veinticinco centavos diarios por recolectar café. Ver: http://www.simpatizantesfmln. org, consultado el 11 de noviembre de 2016. A esta fecha, el salario mínimo diario agrícola era de $\$ 4$.13. Cincuenta años, y una guerra después, el salario mínimo en el campo apenas ha aumentado poco más de cuatro dólares diarios. Esa es una de las razones, aunque no la única, por la que la sociedad salvadoreña sigue siendo tan excluyente y tan desigual.

20 Cardenal, Rodolfo (1996). 0. c. Pág. 390 y 391.

21 Tomado de: PNUD: Incrementa número de salvadoreños que viven con menos de diez dólares. Pobreza en EI Salvador bajó 5\% en 2013, artículo de Laura Bernal publicado el 25 de agosto de 2014 en Contrapunto, periódico digital salvadoreño.

Ver: http://www.contrapunto.com.sv/archivo2016/nacionales/gobierno/pnud-incrementa-numero-de-salvadorenos-que-viven-con-menosde-diez-dolares, consultado el 16 de noviembre de 2016. 
bién bubo una reducción de aquellos que Vivian con menos de cuatro dólares diario. Esto, sin embargo, no es del todo alentador, pues el indice de personas que mantenían un ingreso no menor a los 50 dólares también recayó."Pasaron de ser parte de la clase media al grupo de los vulnerables", reveló William Pleiter, representante auxiliar de programas del PNUD".22

Por otra parte, el documento Medición multidimensional de la pobreza, publicado por la Secretaría Técnica de la Presidencia de El Salvador en 2015, afirma que el $40.6 \%$ de la población salvadoreña vive en condiciones de pobreza. En el área rural, dicho porcentaje se eleva al $64.4 \%$. Y en el área urbana es de $26.1 \% .{ }^{23} \mathrm{Y}$, por otra parte, la industrialización contaba con un mercado interno demasiado pequeño para absorber toda su producción, de modo que este modelo estaba destinado, a mediano o a corto plazo, a colapsar. Entre tanto, el excedente de la industria manufacturera salvadoreña se volcó al Mercado Común Centroamericano. La balanza comercial fue claramente desfavorable para Honduras, cuya economía estaba mucho menos industrializada que la salvadoreña.

En El Salvador era necesaria una reforma agraria que proporcionase a los campesinos el poder adquisitivo mínimo para acceder a los bienes manufacturados. Pero la estructura de propiedad de la tierra, altamente concentrada en pocas manos, era intocable. Debido a esto, "...la Agencia Internacional para el Desarrollo se concentró en el control natal, la construcción de clínicas de salud pública y la obra preferida por el Cuerpo de paæ: las canchas de baloncesto ${ }^{\prime 24}$. Aunque el sector manufacturero creció "un impresionante 24 por ciento, el empleo aumentó un exiguo 6 por ciento en dicho sector, porque la industrialización estaba basada en tecnología intensiva. Además, sacó del mercado a los pequenos productores artesanales, quienes no encontraron empleo. Las decenas de miles que llegaron a San Salvador, expulsados del campo y buscando una vida mejor, vieron sus expectativas frustradas. Tuvieron que conformarse con vivir en los tugurios de la capital, los cuales crecieron de manera asombrosa en esos años... La agricultura seguía siendo la piedra angular de la economía... pero sin reforma agraria y con una tasa de natalidad del 3 por ciento anual, las condiciones en el campo empeoraron para los campesinos y los trabajadores sin tierra. La diversificación de los cultivos, propuesta por los reformistas, expulsó a más campesinos para hacer lugar a las nuevas plantaciones de algodón y caña de azúcar. Mientras el resto del país experimentaba el triunfo aparente del ange económico y de unas posibilidades supuestamente ilimitadas, en el campo, la mayor parte de la población se sumía en la desesperación." 25

22 Tomado de: PNUD: Incrementa número de salvadoreños que viven con menos de diez dólares. Pobreza en El Salvador bajó 5\% en 2013, artículo de Laura Bernal publicado el 25 de agosto de 2014 en Contrapunto, periódico digital salvadoreño.

Ver: http://www.contrapunto.com.sv/archivo2016/nacionales/gobierno/pnud-incrementa-numero-de-salvadorenos-que-viven-con-menosde-diez-dolares, consultado el 16 de noviembre de 2016.

23 STPP y MINEC-DIGESTYC (2015). Medición multidimensional de la pobreza. El Salvador. S. S.: Secretaría Técnica y de Planificación de la Presidencia y Ministerio de Economía, a través de la Dirección General de Estadística y Censos.

24 Cardenal, Rodolfo (1996). 0. c. Pág. 391.

25 Cardenal, Rodolfo (1996). 0. c. Pág. 392. 
Ante esta situación, la población rural empezó a organizarse. A partir de 1965 surgieron una serie de asociaciones que conformaron la Federación Cristiana de Campesinos Salvadoreños (FECCAS) que pretendían la distribución de la tierra, mejores salarios y condiciones de vida dignas en el campo. Pero también comenzaron a aparecer organizaciones paramilitares que se dedicaron a hostigar y a reprimir a la población campesina. El más importante de estos grupos fue ORDEN, Organización Democrática Nacionalista, creada por Rivera en 1966 con campesinos licenciados del ejército, cuya finalidad era "defender al país del comunismo y de la subversión internacional" y apoyar al Partido de Conciliación Nacional, el partido oficial. Las arbitrariedades y abusos de estos grupos paramilitares produjeron asesinatos, venganzas, crímenes y alteraron permanentemente las relaciones sociales en el campo. A partir de esta época, la población rural se polarizó, y los ánimos se prepararon para el conflicto armado.

En 1966, Rivera impuso a su sucesor, el general Fidel Sánchez Hernández (1917-2003), quien resultó electo presidente en 1967. Fue a este militar al que le tocó enfrentar las consecuencias del agotamiento del modelo económico impulsado a principios de los años sesenta y que se tradujo en el hundimiento del Mercado Común Centroamericano. Este agotamiento provocó también el deterioro de las condiciones de vida de los sectores subalternos y asalariados, que habían empezado a organizarse y a presentar demandas. En 1967 hubo una huelga general impulsada por los sindicatos: "La conflictividad social empezó a hacerse sentir en 1967 con el desarrollo de varias huelgas. La de los trabajadores de la fábrica textil IUS A, en febrero, resultó exitosa. En abril una buelga en la empresa metalúrgica ACERO, ubicada en Zacatecoluca, en el interior del país, fue contestada con despidos. Provocó, de inmediato, una buelga de solidaridad. Se sumaron a ella los obreros ferroviarios y los descargadores de los puertos de Acajutla y de Cutuco. Dos dias más tarde, las dos principales centrales sindicales hacian un llamado a la huelga general, el cual era seguido en la mayoría de las más importantes empresas. Fuentes sindicales cifraban, tal vez exageradamente, en 35 mil los obreros en paro. La patronal, presionada por el gobierno y por la gremial de la empresa privada, tuvo que ceder. Los despedidos fueron readmitidos. Habian sido dos primeras victorias. En septiembre la lucha de los panificadores fracasó. Pero la clase obrera y la oposición habian levantado su moraly su disposición de lucha". ${ }^{26} \mathrm{En}$ 1968 se produjo la huelga de ANDES 21 de junio, la principal organización magisterial salvadoreña de la época. Esta huelga, una de las más largas del país, duró cincuenta y seis días. También el ejército demandó mayor presupuesto y el gobierno de Estados Unidos comenzó a proporcionarle entrenamiento contrainsurgente. ${ }^{27}$

26 Ribera, Ricardo. El año histórico de 1968. Diez acontecimientos que cambiaron el mundo. Versión digital: http://www.uca.edu.sv/facultad/chn/ c1170/ribera6.pdf, consultada el 11 de noviembre de 2016.

27 Cardenal, Rodolfo (1996). 0. c. Pág. 393. 
A ese respecto, el historiador Ricardo Ribera amplía: "El 21 de junio de 1968, un día antes del Día del Maestro, el magisterio nacional de El Salvador se proclamaba en huelga general. El movimiento sería impactante para la sociedad salvadoreña y premonitorio del potente movimiento opositor de masas que se desarrollaría durante la década siguiente. Una de las claves de las revoluciones centroamericanas de los ochenta sería la masividad y beligerancia de un movimiento popular que empezó a gestarse, en el caso salvadoreño, en la coyuntura de 1967-1968. Señala el arranque de la crisis social como consecuencia del fiasco en que derivó el proceso de integración económica de la región, conocido como Mercado Común Centroamericano. Su fracaso provocó la guerra entre El Salvador y Honduras de 1969 y sentaba las bases para la exacerbación de las contradicciones sociales a todo lo largo de la década de los setenta". 28

La mal llamada Guerra del Fútbol no duró ni una semana, pero significó la muerte de varios miles de salvadoreños y hondureños, la repatriación forzosa de cerca de $130 \mathrm{mil}$ salvadoreños que trabajaban y vivían en Honduras y la pérdida de vivienda para unas cien mil personas. Todo eso, como afirma Cardenal, puso "más presión en la ya precaria situación rural... Cuatro días de guerra costaron a El Salvador veinte millones de dólares: el 20\% del presupuesto nacional". 29 Si bien el general Sánchez Hernández intentó llevar adelante un programa de reforma agraria, tropezó con la oposición decidida de los terratenientes. Idéntica suerte enfrentaría su sucesor, el coronel Arturo Armando Molina (1927- ), quien llegó a la presidencia en 1972 por uno de los que la juventud militar calificó en 1979 como "escandalosos fraudes electorales'30, "ganando" unas elecciones en las que su contendiente fue el ingeniero José Napoleón Duarte (1925-1989), líder del Partido Demócrata Cristiano. Como candidato a la vicepresidencia lo acompañó Guillermo Manuel Ungo (1931-1991), dirigente del Movimiento Nacional Revolucionario, de inclinación socialdemócrata. Entre tanto, las organizaciones sindicales que venían trabajando desde los años 20 y 30, habían intensificado sus acciones organizativas y de lucha a medida que el sector industrial había crecido, dando lugar a una creciente clase obrera urbana, a pesar de que la mayor parte de la población todavía vivía de y en el agro.

Desde el punto de vista de la izquierda, un resumen de las luchas sindicales durante buena parte del siglo XX es la que nos ofrece el artículo titulado "Las luchas populares del siglo XX en El Salvador", firmado por Roberto Pineda: "En la tercera década (1920-1930) presenciamos el inicio de un vigoroso movimiento popular que tiene diversas vertientes: la sindical que se expresa en la Federación Regional

28 Ribera, Ricardo. El año histórico de 1968. Diez acontecimientos que cambiaron el mundo. Versión digital: http://www.uca.edu.sv/facultad/chn/ c1170/ribera6.pdf, consultada el 11 de noviembre de 2016.

29 Cardenal, Rodolfo (1996). 0. c. Pág. 393 y s.

30 Proclama de la Fuerza Armada, del 15 de octubre de 1979.

https://es.wikisource.org/wiki/Proclama_de_la_Fuerza_Armada_de_la_Rep\%C3\%BAblica_de_El_Salvador, consulta del 11 de noviembre de 2016. 
de Trabajadores Salvadoreños; en la creación desde la FRTS de puentes entre el trabajo urbano y el trabajo con sectores campesinos e indígenas; en el surgimiento de sectores obreros reformistas, anarcosindicalistas y marxistas y sus canales de lucha ideológica, en la creación de instancias de solidaridad internacional con la lucha sandinista así como de apoyo a las victimas de la reacción, como es el Socorro Rojo Internacional..."." 31

El 30 marzo de 1930 había sido fundado el Partido Comunista por los dirigentes Abel Cuenca, Miguel Mármol y Modesto Ramírez, teniendo entre otros miembros conocidos a Agustín Farabundo Martí. Esta agrupación realizó labores de proselitismo sobre todo en el campo. En enero de 1932, como ya se mencionó anteriormente, ocurrió la sublevación de grupos campesinos en la zona cafetalera del occidente de El Salvador. La represión que siguió a la insurrección campesina no solo despojó a los sectores de izquierda de buena parte de su base social, sino que consiguió ilegalizar al movimiento popular. Los comunistas sobrevivientes pasaron a la clandestinidad.
Algunos soportaron varios años de cárcel. ${ }^{32}$ Entre 1940 y 1950, Pineda añade: “...los comunistas y sectores democráticos unifican fuerzas y desarrollan las gloriosas jornadas de abril, mayo y diciembre de 1944. El 2 de abril se produce un levantamiento cívico-militar que es derrotado por el dictador Martinez. A principios de mayo se convoca a una Huelga General de Brazos Caidos que el 9 de este mes logra derrocar al tirano. En octubre hay un contragolpe reaccionario ${ }^{33}$ y en diciembre de ese año contingentes de militares y jóvenes democráticos incursionan desde Guatemala para combatir la dictadura, pero son derrotados". ${ }^{34}$

En la década de los cincuenta, "los comunistas y los sectores democráticos sufren la represión del régimen osorista, llegado al gobierno en 1948. Posteriormente los comunistas reactivan el trabajo universitario y sindical, y logran la publicación de Opinión Estudiantil y fortalecer AGEUS ${ }^{35}$ asi como crear en 1957 la Confederación General de Trabajadores Salvadores, CGTS. Forman en 1958 el Movimiento Revolucionario Abril y Mayo y el Frente Nacional de Orientación Civica, FNOC, para enfrentar a la dictadura militar lemusista". ${ }^{36}$

31 Pineda, Roberto (2010). Las luchas populares del siglo XX en El Salvador". En SIEP, Servicio Informativo Ecuménico y Popular. En www.ecumenico. org. Publicado el 9 de octubre de 2010 y consultado el 15 de noviembre de 2016.

32 Ver: Dalton, Roque (2005). Miguel Mármol, los sucesos de 1932 en El Salvador. San Salvador, UCA Editores. ISBN 978-99923-34-96-6.

33 Esto sería el golpe de Osmín Aguirre.

34 Pineda, Roberto (2010). Las luchas populares del siglo XX en EI Salvador". En SIEP, Servicio Informativo Ecuménico y Popular. En www.ecumenico. org. Publicado el 9 de octubre de 2010 y consultado el 15 de noviembre de 2016.

35 Asociación General de Estudiantes Universitarios Salvadoreños. Para conocer más acerca de esta organización y de la historia del movimiento estudiantil salvadoreño durante el siglo XX, ver Quezada, Rufino y Martínez, Hugo Roger (2008). Veinticinco años de estudio y lucha. San Salvador, Editorial Universitaria. Segunda edición. Hay versión digital en línea: http://passthrough.fw-notify.net/download/188065/http://www. ues.edu.sv/descargas/25_años_de_estudio_y_lucha.pdf, consultada el 23 de noviembre de 2016. Según esta fuente, AGEUS fue fundada en 1927. Algunos de sus primeros dirigentes e integrantes fueron Agustín Farabundo Martí, Alfonso Luna y Mario Zapata, quienes fueron fusilados por el gobierno del general Maximiliano Hernández Martínez el 1 de febrero de 1932. Fuentes de este último dato: partidas de defunción de los tres fusilados. 
Fue en 1950 cuando el panadero Salvador Cayetano Carpio fundó el Comité de Reorganización Obrera Sindical Salvadoreña (CROSS), una agrupación de sindicatos comunistas. Capturado por la policía de Óscar Osorio en 1952, Carpio pasó dieciocho meses en la cárcel antes de ser expulsado del país. Se refugió en México, y ahí escribió el libro Secuestro y capucha $a^{37}$, donde recogió las experiencias de su estadía en prisión. Luego viajó a la Unión Soviética y estudió en la Escuela de Cuadros del PCUS. A su regreso a El Salvador, en 1963 consiguió vincularse de nuevo con el Partido Comunista Salvadoreño. También hizo prevalecer la preeminencia dentro de esa organización de cuadros provenientes del movimiento obrero ${ }^{38}$. En 1961 el Directorio Cívico Militar lanzó al exilio y a la cárcel a los dirigentes del PCS y del movimiento popular. Aun así, en 1964 Carpio fue electo secretario general del PCS, y tres años más tarde dirigió la huelga de la fábrica ACERO. Al mismo tiempo, el PCS estaba participando en las elecciones como parte del Partido Acción Renovadora, PAR.

En esa misma oportunidad, el médico Fabio Castillo Figueroa, quien había sido rector de la Universidad de El Salvador, UES, de 1963 a 1967, desafió el orden establecido como candidato presidencial desde las filas del
PAR al plantear la necesidad de una reforma agraria. Tales ideas, por supuesto, solo despertaron recelos y fuerte oposición en los sectores empresariales y terratenientes ${ }^{39}$. Se agudiza en esta época, una serie de conflictos entre los sectores más vulnerables y empobrecidos de la población y los sectores económica y políticamente poderosos, los cuales irían exacerbándose paulatinamente en la década siguiente hasta desembocar en la guerra civil (1980-1992). La formación social salvadoreña, gestada desde el siglo XIX sobre la expropiación de las tierras comunales, el monocultivo agroexportador del café, y la exclusión y la marginación de los trabajadores del agro y de la industria manufacturera, no haría sino profundizar sus contradicciones, en una escalada de violencia cuyas consecuencias todavía sufrimos hasta ahora.

\subsection{Roque Dalton, resumen biográfico}

Roque Antonio Dalton García nació en el barrio de San José, en la ciudad de San Salvador, el 14 de mayo de 1935. Hasta la fecha, esta es una zona de clase media baja ubicada al norte de la capital, cerca del municipio dormitorio de Mejicanos. Sus padres, el empresario estadounidense Winall Agustín Dalton y la enfermera salvadoreña

Pineda, Roberto (2010). Las luchas populares del siglo XX en EI Salvador". En SIEP, Servicio Informativo Ecuménico y Popular. En www.ecumenico. org. Publicado el 9 de octubre de 2010 y consultado el 15 de noviembre de 2016.

37 Carpio, Salvador Cayetano (1979). Secuestro y capucha en un país del mundo "libre". San José de Costa Rica, EDUCA. ISBN 9788483600191.

38 Entrevista de la autora con Jorge Arias Gómez. Ciudad Universitaria, San Salvador, 1998.

39 Pineda, Roberto (2010). Las luchas populares del siglo XX en El Salvador. En SIEP, Servicio Informativo Ecuménico y Popular. En www.ecumenico. org. Publicado el 9 de octubre de 2010 y consultado el 15 de noviembre de 2016. 
María García Medrano, jamás contrajeron matrimonio, hecho que lo obligó a soportar el estigma de ser "hijo natural" en el seno de una sociedad tan retrógrada e hipócrita como la salvadoreña.

Además de ejercer su oficio de enfermera, María García Medrano era propietaria de una tienda, "La Royal", hoy desaparecida, situada en la esquina de la Segunda Avenida Norte y la Calle "5 de noviembre", en la ciudad de San Salvador. Dice Carlos Cañas Dinarte: "Allí, un primo de su madre, Santiago Díaz Medrano, le enseñó los rudimentos de la escritura y la lectura. Gracias al apoyo financiero de su padre y a los esfuerzos de su progenitora, realizó sus estudios en el colegio privado Santa Teresita del Niño Jesús, fundado el 2 de mayo de 1920". ${ }^{40}$

Este centro educativo fue dirigido por las educadoras españolas María y Mercedes Gonzalbo. Roque Dalton continuó posteriormente sus estudios en los colegios Bautista y Externado de San José. Esta última era, y todavía es, una institución educativa jesuita a la que ingresó en 1946 y de la que se graduó como bachiller en Ciencias y Letras en 1952. Además, el futuro poeta recibió clases de inglés de la profesora Lillian Pohl Müller de Galindo, la abuela del poeta David Escobar Galindo, quien en aquellos años residía al final del pasaje Rovira, en las cercanías de la tienda y residencia de doña María García.
Según la misma fuente, a continuación Roque Dalton realizó estudios de Jurisprudencia, Ciencias Sociales y Etnología en la Universidad Católica de Chile (1953) y en las estatales de El Salvador (1954-1959) y México (1961).En mayo de 1954 ingresó a la Asociación de Estudiantes Universitarios (AEU) de la Universidad de El Salvador. Al año siguiente participó en las tertulias artísticas celebradas en "El rancho del artista", centro cultural fundado y dirigido en la ciudad de San Salvador, a partir de 1955, por la escritora hondureña Clementina Suárez. En 1956 fue miembro fundador del Círculo Literario Universitario y participó en la puesta en escena de la obra teatral La Alondra, del escritor francés Jean Anouilh (1910-1987), basada en la vida de Juana de Arco.

En junio del mismo año fue secretario de la primera comisión del Congreso Estudiantil Universitario, y comenzó a trabajar para el primer noticiero de la televisión salvadoreña, Teleperiódico, así como para Teleperiódico impreso, empresas dirigidas por su amigo Álvaro Menéndez Leal. La misma fuente afirma que, en 1957, Roque Dalton viajó a Moscú, como uno de los representantes salvadoreños ante el VI Festival de la Juventud y los Estudiantes por la Paz y la Amistad, organizado por la Federación Mundial de la Juventud Democrática (FMJD) y la Unión Internacional de Estudiantes (UIE). En ese mismo año el poeta se afilió al Partido Comunista Salvadoreño (PCS), dentro del que militó por más de una década. Se desempe- 
ñó como codirector de la revista estudiantil de la Facultad de Derecho de la Universidad de El Salvador. En 1959 viajó a Santiago de Chile para cubrir periodísticamente hablando la reunión anual de la Organización de Estados Centroamericanos (OEA).

Cañas Dinarte sostiene que: "En 1958, la radio YSKL dio a conocer el programa noticioso y crítico Mediodía, dirigido por el doctor Oswaldo Escobar Velado y el cual contaba con reporteros como Dalton y los también escritores José Roberto Cea y Jorge Campos. Durante las transmisiones sabatinas, ese espacio radiofónico difundía el suplemento cultural Toro de espuma: antología de la palabra. Por el nivel de sus críticas, el espacio informativo y su complemento cultural fueron censurados pocos meses más tarde por el régimen del teniente coronel José María Lemus. Sus conductores fueron salvados de ser capturados por la policía gracias a una amplia manifestación popular, convocada por los propios locutores durante la última emisión del programa". ${ }^{41}$

$\mathrm{Al}$ año siguiente Roque Dalton viajó de nuevo a Chile junto con el escritor Álvaro Menén Desleal, con el propósito de dar cobertura periodística a la $\mathrm{V}$ Reunión de Cancilleres de América. Dalton y Roberto Armijo, también escritor, participaron, después, en un homenaje poético al $\mathrm{X}$ aniversario de fundación de la Facultad de Humani- dades de la Universidad de El Salvador. En 1960 asistió en Guatemala por invitación de los estudiantes de Derecho de la Universidad de San Carlos (USAC). Por razones políticas, los dos jóvenes intelectuales salvadoreños fueron capturados al salir del avión en el Aeropuerto "La Aurora", pero fueron liberados y devueltos a El Salvador a los pocos días.

El gobierno de José María Lemus lo acusó de organizar los desórdenes callejeros universitarios ocurridos el 13 de diciembre de 1959, motivo por el que fue capturado y puesto a las órdenes del Juzgado Quinto de lo Penal. "Por falta de pruebas contundentes que justificaran su detención, fue liberado, bajo fianza, a las 12:30 horas del viernes 8 de enero de 1960 ". ${ }^{42}$ A su paso por la cárcel constató las duras condiciones de más de un centenar de reos sin condena presos en la Penitenciaría Central de San Salvador, lo que lo llevó a iniciar"una cruzada dentro de la Asociación de Estudiantes de Derecho (AED) de la Universidad de El Salvador, con el fin de darles asistencia jurídica gratuita. ${ }^{43}$

Fue detenido de nuevo el 25 de agosto de 1960 en las inmediaciones del capitalino Parque Infantil de Diversiones y "desaparecido" por varias semanas. Afirma la misma fuente: "amenazado de muerte por sus captores, fue incomunicado en las bartolinas del cuartel central de la Policía Nacional (donde no fue

41 Cañas Dinarte (2004). 0. c.

42 Cañas Dinarte (2004). 0. c.

43 Cañas Dinarte (2004). 0. c. 
registrado su ingreso como reo) y en el fatídico "callejón número nueve" de la Penitenciaría Central (San Salvador, hoy Fondo Social para la Vivienda).Fue liberado junto con otros reos políticos tras el derrocamiento de Lemus, en la mañana del miércoles 26 de octubre de 1960. Fue recibido y vitoreado en las afueras del reclusorio por una multitud compuesta por veinticinco mil personas. Poco después, rindió su declaración como ofendido en contra de sus captores, en los tribunales de la capital salvadoreña. Su testimonio de esas semanas de inhumana detención fue narrado por él mismo en tres artículos, aparecidos en la sección editorial de El Diario de Hoy, en diciembre de ese mismo año. Gracias a su denuncia y a otras muchas, el "callejón número nueve" fue demolido entre febrero y marzo de 1961. En una ceremonia desarrollada en Casa Presidencial (barrio de San Jacinto), a partir de las 11:00 horas del sábado 5 de noviembre de 1960, la golpista Junta de Gobierno entregó a la Asociación General de Estudiantes Universitarios Salvadoreños (AGEUS) las fichas de cada uno de los estudiantes detenidos, entre las que se encontraba la de Dalton, cuyas fotos fueron incluidas en la edición mexicana de Taberna y otros lugares (edición definitiva, México D. F., 1988, con un poema agregado de cuatro partes y palabras prologales de Eraclio Zepeda).Tras el golpe realizado por el Directorio Cívico Militar contra la Junta de Gobierno (enero de 1961), la inseguridad e inestabilidad so- cial reinantes en el país lo condujeron fuera de las fronteras nacionales. Vivió y trabajó en Guatemala, México y La Habana, ciudad... en la que laboró como comentarista para Radio Habana y la agencia noticiosa Prensa Latina. Además, frecuentó los locales de Casa de las Américas y la Unión de Escritores y Artistas Cubanos (UNEAC)". ${ }^{44}$

En Cuba entabló amistades duraderas y conquistó la admiración de muchas figuras de la intelectualidad de la época. Fue en La Habana donde conoció a su hermana Margarita Dalton (nacida en México, en 1943), por entonces estudiante de Antropología en la universidad local y quien ganaría un concurso de novela juvenil en su ciudad natal (1967), con su Larga Sinfonía en D y babía una ver, un homenaje a la droga hippie LSD. Fue durante su primera estancia en la capital cubana cuando su poemario El turno del ofendido fue galardonado con mención honorífica en el certamen Casa de las Américas (La Habana, 1962). En El Salvador, su cuento escénico El juicio del día fue divulgado por la revista Vida universitaria (San Salvador, nos. $6-7,1962) .^{45}$

A pesar de saber que su vida se vería amenazada, Roque Dalton retornó a El Salvador en 1963. Fue capturado nuevamente en septiembre de 1964 y recluido en el penal de Cojutepeque. Se fugó de esta prisión a raíz del sismo del 3 de mayo de 1965, que provocó el derrumbe de una de las paredes

\footnotetext{
44 Cañas Dinarte (2004). 0. c.
}

45 Cañas Dinarte (2004). 0. c. 
de su celda. De regreso en Cuba, formó parte del consejo de colaboradores de la revista Casa.

$\mathrm{Al}$ año siguiente viajó a Praga, entonces capital de Checoslovaquia, donde trabajó en el comité de redacción de la revista internacional Problemas de la pazy el socialismo. "Allí, redactó un complejo trabajo poético experimental, basado en los "poemas-problemas" y en sus constantes visitas a la taberna U’Fleku. Amparado con el seudónimo "Farabundo", presentó el manuscrito de este poemario al certamen literario continental y anual de Casa de las Américas (La Habana, Cuba, 1969) en el que su libro Taberna y otros lugares obtuvo el primer premio". ${ }^{46}$

Fue en la capital de Checoslovaquia donde realizó las entrevistas al líder obrero Miguel Mármol, quien había salvado la vida de manera providencial en 1932. De dichas entrevistas nació el libro testimonial Miguel Mármol (San José, Costa Rica, 1972. Hay traducción al inglés realizada por Kathleen Ross y Richard Schaaf, con prólogos de Manlio Argueta y Margaret Randall, 1986). $\mathrm{El}$ autor se reencontró con su esposa Aída y sus tres hijos - Roque Antonio, Juan José y Jorge Vladimiro- en Praga en 1967. Posteriormente, ese mismo año se trasladó a Cuba, desde donde viajó a Sur América, Europa, Rusia, Corea del Norte y Vietnam. En 1970, Dalton, quien ya contaba treinta y cinco años, renunció a su trabajo como miembro del Comité de Colaboración de Casa de las Américas y recibió un intenso entrenamiento militar, motivado por su deseo de ingresar a los movimientos guerrilleros centro y latinoamericanos. Tres años más tarde viajó a Chile por invitación del gobierno socialista de Salvador Allende, desde donde regresó a El Salvador con una nueva identidad: "Julio Delfos Marín".

Se integró al Ejército Revolucionario del Pueblo (ERP), organización clandestina cuyos dirigentes lo capturaron el 13 de abril de 1975. Lo enjuiciaron al día siguiente en un proceso durante el cual lo defendió el poeta Eduardo Sancho, conocido como "comandante Fermán Cienfuegos"). Fue ejecutado a tiros por orden de los dirigentes Domingo Mira ("Sebastián Urquilla") y Joaquín Villalobos."Aunque los datos existentes son aún confusos y obran en poder exclusivo de los participantes de ese hecho sangriento, la información disponible permite establecer que Dalton murió en una casa del barrio Santa Anita y que después fue trasladado a las cercanías volcánicas de Quezaltepeque, el 10 de mayo de 1975. En esa zona rural, su cuerpo fue abandonado, devorado por animales, semienterrado, descubierto por autoridades y perdido para siempre en una barranca, según lo estableció, en 1993, un informe de la Misión de Observadores de las Naciones Unidas para El Salvador (ONUSAL)". ${ }^{47}$ 
Sus trabajos aparecieron en muchas publicaciones de El Salvador, Cuba y México, entre las que se cuentan Hoja, La Jodarria, Opinión estudiantil (órgano universitario salvadoreño del que fue corredactor en 38 números de su decimocuarta época, entre junio de 1955 y julio de 1956), La Universidad, Gallo gris, Tribuna libre, El independiente (del cual fue redactor), Letras de Curcatlán, Abrily Mayo, Diario Latino, La Prensa Gráfica, El Diario de Hoy, Vida universitaria, Marcha, Tláloc, La pájara pinta, La gaceta de Cuba, El caimán barbudo y más.

Publicó los libros Dos puños por la tierra (poesía, San Salvador, 1955, en coautoría con el poeta y revolucionario guatemalteco Otto René Castillo), Mía junto a los pájaros (San Salvador, 1958), La ventana en el rostro (poesía, México, 1961, con prólogo de Mauricio de la Selva), El mar (poesía, La Habana, 1962, en edición de diez páginas patrocinada por la librería "La Tertulia", propiedad de Fayad Jamís), El Salvador (monografía, La Habana, 1963), Los testimonios (poesía, La Habana, UNEAC, 1963, 75 págs.), César Vallejo (ensayo, La Habana, 1963, 50 págs.), El otro mundo (1963), Poemas (San Salvador, 1967), El intelectual y la sociedad (conversaciones con escritores, México D. F., 1969. Existe una traducción al italiano, realizada ese mismo año), Los pequeños infiernos (poesía, Barcelona, 1970, con palabras de José Agustín Goytisolo), ¿Revolución en la revolución? y la crítica de derecha. (La Habana, 1970), Las historias prohibidas del Pulgarcito (prosas y poemas, México D. F., 1974), Pobrecito poeta que era yo (novela, titulada alguna vez como
Los poetas, San José, Costa Rica, 1976. Hay traducción al alemán -ArmerklienerDichter, der Ichwar-, realizada por Silvia Pappe, y publicada en Basel, RotpunktVerlag, 1986), Caminando y cantando (pieza dramática, San Salvador, revista Abra, 1976), Poemas clandestinos (San Salvador, 1980), Los helicópteros (pieza dramática, escrita en colaboración con "Peperuiz", pseudónimo del escritor y abogado Dr. José Napoleón Rodríguez Ruiz, San Salvador, 1980), Las enseñanzas de Viet-Nam (apuntes, California, 1981), Un libro rojo para Lenín(poesía, Managua, 1986) y Un libro levemente odioso (poesía, México D. F., 1988).

Los poemas de Roque Dalton aparecen en muchas antologías publicadas en ediciones bilingües en Europa, Estados Unidos Centro y Sur América, como En la humedad del secreto (recopilación de poemas dispersos y antología crítica, preparada por Rafael Lara Martínez, San Salvador, Dirección de Publicaciones e Impresos, 1994, con reimpresión en mayo de 1995), Small hours of the night (Willimantic, CubstonePress, 1996, edición de Hardie Saint Martín que recibió un premio estadounidense a la mejor traducción al inglés en 1997, gracias a las versiones hechas por Jonathan Cohen, James Graham, Paul Pines y otros), Antología minima (selección de Luis Melgar Brizuela, San José, Costa Rica, EDUCA, 1998) y La ternura no basta (con prólogo de Víctor Casaus, La Habana-Sevilla, Fondo Editorial Casa de las Américas-Área de Cultura de la Diputación de Sevilla, 1999, 478 págs.). 


\section{AKADEMOS \\ Parte 2: Análisis del poema "Porqué escribimos".}

\section{Temática, contenido, métrica y figuras literarias}

Este poema es una composición en verso libre que pertenece al tercer poemario que Roque Dalton publicó en vida. Después de su obra debut: Dos puños por la tierra, publicada en San Salvador, en 1955, en coautoría con el poeta y revolucionario guatemalteco Otto René Castillo, y del poemario titulado Mí junto a los pájaros (San Salvador, 1958), Roque Dalton publicó otro poemario: La ventana en el rostro, en la ciudad de México, en 1961, con prólogo del escritor y militante de izquierda salvadoreño Mauricio de la Selva. La ventana en el rostro es una obra de juventud, ya que en 1961 el autor cumplió veintiséis años. Pero hay que matizar: a los veintiséis años Roque Dalton ya había pasado al menos dos veces por la cárcel, había luchado con éxito por derrocar al gobierno militar de José María Lemus, estuvo por primera vez en Chile, donde conoció a Diego Rivera, y en Moscú, en donde tomó contacto con el llamado "socialismo real". A pesar de sus pocos años, el autor ya tenía cierta andadura vital, política y literaria.
La temática de este poema es un verdadero Ars poetica, o Arte poético, esto es, una declaración de los principios en que se basa el trabajo literario del autor. ${ }^{48}$ Nos entrega, explícitas, las razones por las cuales escribe. Y para explicarlas, recurre a una de las figuras literarias que le son más queridas, habida cuenta de las numerosas ocasiones en que echó mano de ella: la enumeración. De esta manera, construye una acumulación de hechos, cosas y gentes que van amplificando, como los círculos concéntricos en un estanque cuando alguien arroja una piedra, el sentido y la emoción en un "crescendo" que se resuelve al final, casi siempre en un epifonema lapidario ${ }^{49}$.

De esta manera progresiva el autor va construyendo un tono emocional dentro de una serie de sintagmas verbales que nada tiene de azarosa, ni de espontánea. No hay nada de improvisado ni de "natural" en este poema de Dalton. Por el contrario, cada término está colocado por una razón. Todo el primer párrafo gira en torno a un verbo principal: "Uno hace versos y ama". El subrayado es nuestro. A ese verso corresponden tres complementos directos:

1. La extraña risa de los niños. Este sintagma
podría ser una metáfora de la infancia. sus textos esenciales, en la página 13, afirma que el arte poética, y se refiere a David Escobar Galindo, es: la declaración de principios poéticos, y también de principios vitales, del autor. Ver: Revista Akademos. Antiguo Cuscatlán, Universidad “Dr. José Matías Delgado". Año 11 Vol. 2, no 29 Julio-diciembre 2017. ISSN: 1995-4743. Hay versión en línea: https://www.lamjol.info/index.php/akademos/article/view/6318/6046

49 Epifonema. Figura retórica. El Diccionario de la Lengua Española define el término de la siguiente manera: 1. m.Ret.Exclamaciónreferidaaloqueanteriormenteseha dicho, conlacualsecierraoconcluyeelpensamientoaque pertenece. Era u. t. c. f. 
2. El subsuelo del hombre/ que en las ciudades ácidas disfraza su leyenda. Posible metáfora del proletariado urbano.

3. La instauración de la alegrial que profetiza el bumo de las fábricas. Acá encontramos una posible metáfora de la revolución y alude nuevamente al proletariado urbano.

Aquí conviene hacer una nota al margen: cuando La ventana en el rostro fue publicado en México, en 1961, en El Salvador estaba formándose un sector industrial manufacturero de cierta pujanza gracias a la construcción de la primera presa hidroeléctrica con la que contó el país: la 5 de noviembre, conocida popularmente como "la Chorrera del Guayabo", inaugurada el 21 de junio de $1954^{50}$, durante el gobierno de Óscar Osorio (19101969), antecesor de José María Lemus. Fue este proyecto de infraestructura el que dotó al país de la energía necesaria para la electrificación de los principales núcleos urbanos y para el funcionamiento de las nacientes fábricas. Este fue el detonante para la aparición o, al menos, para el crecimiento a niveles masivos de un importante proletariado urbano proveniente del éxodo del campo a la ciudad, proletariado que vino a asentarse en las nacientes "villas miseria" o cinturones de pobreza que comenzaron a surgir en los alrededores de la capital y municipios aledaños. Es a esta realidad a la que Dalton hace referencia. En el siguiente párrafo el autor echa mano, una vez más, a la enumeración. Afirma: "Uno tiene en las manos..:
1. Un pequeño país. Alude aquí, ¿qué duda cabe?, a la pequeñez territorial de El Salvador.

2. Horribles fechas. Ya entonces, y más hoy en día, nuestra historia está llena de fechas nefastas. Podría ser una alusión velada a los sucesos de 1932.

3. Muertos como cuchillos exigentes. El sentido es obvio. Desde el punto de vista retórico, este verso recoge un símil.

4. Obispos venenosos. Alude aquí al sector ultraconservador de la Iglesia Católica, plegado a los intereses de los poderosos.

5. Inmensos jóvenes de pie/sin más edad que la esperanza. Al leer esto pienso en Víctor Manuel Marín, uno de los héroes, hoy olvidados, del levantamiento militar del 2 de abril de 1944, a quien Oswaldo Escobar Velado mencionó en un poema. ${ }^{51}$

6. Rebeldes panaderas con más poder que un lirio. ¿Hay aquí una velada alusión a Salvador Cayetano Carpio, líder sindical del sector de panificadores?

7. Sastres como la vida. Esta es una posible alusión al líder de izquierda Miguel Mármol, de oficio sastre.

8. Páginas

9. Novias

10. Esporádico pan. Esta imagen, con su poderoso epíteto, aluden a la pobreza. En buen salvadoreño remite al refrán: Coyol quebrado, coyol comido.

11. Hijos enfermos. Otra alusión, esta vez aún más violenta, a la pobreza.

50 Ver: https://www.cel.gob.sv/central-hidroelectrica-5-de-noviembre/, consultado el 20 de mayo de 2019.

51 Ver: https://marcialteniarazon.org/galeria/relatos/aurora-del-2-abril-1944, visitado el 20 de mayo de 2019. 
12. Abogados traidores/nietos de la sentencia y lo que fueron/bodas desperdiciadas de impotente varón. Convendría aquí trazar un vínculo de intertextualidad con el poema Vida, pasión y muerte del antihombre, de Pedro Geoffroy Rivas. ${ }^{52}$

13. Madre,

14. Pupilas, (Aquí la ambigüedad no está despejada: ¿se refiere a las pupilas de los ojos? En El Salvador se les llamaba, y todavía se llama así, "pupilas" a las señoritas que viven en habitaciones de alquiler. Con frecuencia se trata de jóvenes estudiantes que vienen a la capital a seguir estudios universitarios).

15. Puentes,

16. Rotas fotografias y programas...

Aquí conviene hacer otra nota al margen para señalar la poderosa selección de epítetos. ${ }^{53}$ Para Roque Dalton, la risa de los niños es "extraña", las ciudades son "ácidas", tal vez por lo que tiene de corrosivo el paisaje urbano. En su poesía, la violencia queda retratada en esos "muertos como cuchillos exigentes". Exigentes porque nos pedirán cuentas, en el sentido evangélico del térmi- no, y aquí el texto nos remite al pasaje de Mateo 25: 35-45: "Porque tuve hambre, y me disteis de comer, etc.". Y otro tanto sucede con los obispos "venenosos".

Roque Dalton no alcanzó a presenciar el breve período durante el cual monseñor Óscar Arnulfo Romero fue arzobispo de San Salvador. El primer santo salvadoreño hubo de soportar la incomprensión, y virulenta oposición en algunos casos, de varios miembros de la Conferencia Episcopal salvadoreña, por no hablar de la campaña de difamación de la que lo hizo víctima un sector oscurantista del gran capital, que llegó a acuñar la ominosa frase: "Haga patria: mate a un cura", a fines de los años setenta y primeros ochenta del siglo XX. Sería tema de otro trabajo explorar la posición de este poeta hacia una iglesia que, al menos en ciertos sectores, estaba cambiando en lo que se refiere a su papel social.

Hay una tercera enumeración, iniciada con el pronombre indefinido usado en un sentido impersonal, como en el famoso tango 54: "Uno se va a morir,/ mañana,/ un año, un

52 Geoffroy Rivas dice, en la parte V de Vida, pasión y muerte del antihombre: "Pobrecito poeta que era yo, burgués y bueno./Espermatozoide de abogado con clientela./ Oruga de terrateniente con grandes cafetales y millares de esclavos./ Embrión de gran señor, violador de mengalas y de morenas siervas campesinas...." El subrayado es mío. Roque Dalton con seguridad conocía este poema de Pedro Geoffroy Rivas, con quien tuvo intensas semejanzas y diferencias. No en balde el verso: Pobrecito poeta que era yo le sirvió posteriormente a Dalton para titular la novela en que nos deja constancia de las andanzas juveniles de su generación.

53 El diccionario antes citado define epíteto como: 1. m. Gram. Adjetivo que denota una cualidad prototípica del sustantivo al que modifica y que no ejerce función restrictiva. En la blanca nieve, blanca es un epíteto.2.m. Palabra o sintagma fijo que tienen una función caracterizadora de personas o cosas. El Cruel fue el epíteto de Pedrol.3.m. Expresión calificativa usada como elogio, más frecuentemente,como insulto. En la discusión se oyeron los más variados epítetos.

54 El tango titulado Uno fue compuesto en 1943 por el argentino Enrique Santos Discépolo, con letra del también argentino Mariano Mores. Sus primeros versos afirman: "Uno busca lleno de esperanzas/ el camino que los sueños prometieron a sus ansias. / Sabe que la lucha es cruel y es mucha, / pero lucha y se desangra por la fe que lo empecina..." 
mes sin pétalos dormidos, / disperso va a quedar bajo la tierra/ y vendrán nuevos hombres/ pidiendo panoramas". El sentido no puede ser más claro: la muerte, esa realidad ineludible que nos alcanzará a todos tarde o temprano, va a suprimir a los testigos de esta época. La poesía es aquí, pues, testimonio de un tiempo concreto, de unos hechos históricos, de las acciones y omisiones de nuestros coetáneos.

La cuarta enumeración: "Preguntarán qué fuimos, / quienes con llamas puras les antecedieron, / a quiénes maldecir con el recuerdo". La historia encarna, aquí, para Dalton, el juicio inapelable dictado por los marginados, por los desposeídos, por los excluidos, por los ofendidos (no en balde uno de sus libros posteriores se habrá de titular El turno del ofendido), por los olvidados, usando el término de la famosa película de Buñuel, contra los privilegiados, los sectores económica y políticamente poderosos, los usufructuarios de la riqueza de la nación, que debería ser para todos y no solo para unos pocos.

El epifonema no podría ser más contundente y se concentra en los tres últimos versos: "Bien./ Eso hacemos: custodiamos para ellos el tiempo que nos toca". En la poesía de Dalton no hay vocablos colocados "porque sí" o antojadizamente. Cada palabra ha sido escogida con cuidado infinito. El verbo es claro: custodiamos. Según el Diccionario de la Lengua Española, custodiar significa, en primera instancia, "guardar algo con cuidado y vigilancia", y en su segunda acepción: "vigilar a alguien, generalmente a un detenido, para evitar que escape".
De esta manera, Roque Dalton nos está diciendo que, desde su concepción de la poesía, y del "deber ser" del poeta, este es el depositario de los hechos históricos de su tiempo, legado que debe guardar "con cuidado y vigilancia", pero también que dicha historia es rehén de este custodio, en la figura del poeta, como representante de los desposeídos, de los excluidos, de los ofendidos y olvidados. En una palabra: de aquel que, como el profeta, es la "voz de los sin voz". La doble significación del verbo custodiar nos indica que su selección y uso no fueron casuales: el poeta guarda, pero también vigila, para que no se tuerza la recta interpretación de la historia. En una palabra: la ortodoxia al estudiar y comprender los hechos de ese "tiempo que nos toca".

Y ese "tiempo que nos toca" también juega con la ambigüedad del verbo "tocar": a) Nos toca: es decir, nos atañe, nos corresponde, y b) Nos toca literalmente. Esto es: posa su mano sobre nosotros, nos percibe (y lo percibimos a la vez) a través del tacto, entramos en contacto con él, lo asimos, o nos toma con sus manos, y tiene, además, por esa cercanía innegable, la posibilidad de vulnerarnos, de golpearnos, de herirnos. El tiempo constantemente nos erosiona, nos desgasta, nos muele con los invisibles dientes de los años, los meses, los días, las horas, los minutos y los segundos.

No en balde la esgrima se considera "el arte de tocar sin ser tocado". Y la poesía no deja de ser una forma superior de esgrima verbal. Nadie comprendió como Roque Dalton 
que la lucha ideológica se libraba, y se libraría, sobre todo en el lenguaje. $Y$ de manera aún más especial en la poesía política. Al menos, tal como él la concebía.

\section{Parte 3: Análisis del "Poema de amor".}

\section{Temática, contenido, métrica y figuras literarias}

La temática de este poema se refiere a la situación de muchos salvadoreños en la época en que el texto se gestó (años sesenta del siglo XX, ya que la primera edición del libro donde aparece el poema, Las historias probibidas del Pulgarcito, es de 1974 y fue publicada en la ciudad de México, D. F.). Se trata de un poema de madurez, si se puede hablar de ello en un hombre que fue muerto cuatro días antes de cumplir cuarenta años. En 1974 Roque Dalton cumplió treinta y nueve años y fue asesinado el 10 de mayo de 1975.

El poema que vamos a analizar está formado, como la mayoría de los del autor, por versos libres. Esto es: sin rima, sin medida homogénea y sin esquemas rítmicos constantes. La temática que aborda es una representación de la marginación, o más bien, de los marginados, ya que las imágenes que nos va planteando nos dibujan el retrato de una nación de hombres y mujeres excluidos, sin acceso a ninguna forma de representación política, ni a la propiedad de los medios de producción, tal como era el caso de la mayoría de los habitantes de El Salvador en aquella época e, incluso, hoy en día.
La estructura del poema se asemeja a la de un decreto. La prolongada enumeración, que constituye la mayor parte del cuerpo del texto, constituye los "considerandos" de este decreto poético. Dicha enumeración, que describe una serie de hechos de explotación muy concretos, acumula un "crecendo" que se resuelve en los dos últimos versos. Ahí, donde el autor dice: "mis compatriotas,/ mis hermanos", encontramos el verdadero epifonema.

Si bien el lenguaje, en la mayor parte del poema, es fundamentalmente denotativo, aquí y allá hay destellos de cierta con notatividad. Veamos la enumeración:

\section{Los que ampliaron el Canal de Panamál "y} fueron clasificados como "silver roll" y no como "gold roll"). Acá conviene explicar que en 1904, cuando el gobierno de los Estados Unidos recibió las obras del Canal de Panamá de manos de los inversionistas franceses, esta mega obra de ingeniería estaba llena de problemas de todo tipo. Uno de los mayores era conseguir suficiente mano de obra, especialmente calificada, para continuar los trabajos. Además, la región era azotada por muy adversas condiciones climatológicas, topográficas y, especialmente, de salubridad. El paludismo y la fiebre amarilla diezmaban las filas de trabajadores y técnicos. En aquella época, y aún ahora, los funcionarios estadounidenses eran racistas. De modo que "clasificaron" a los trabajadores en dos grandes categorías: había un escalafón llamado "gold roll" para los trabajadores "blancos", y 
otro llamado "silver roll" para los de origen amerindio, afrodescendiente $\mathrm{O}$ asiático. La paga y las prestaciones eran muy diferentes en cada bloque. ${ }^{55}$ Es, pues, una expresión de la inequidad, la discriminación, la marginación y la explotación sufrida por los trabajadores solo por el hecho de no ser "blancos" estadounidenses.

2. Los que repararon la flota del Pacifico/ en las bases de California. A partir del 7 de diciembre de 1941, a raíz del ataque japonés a la base naval de Pearl Harbor en Hawaii, los Estados Unidos entraron a la Segunda Guerra Mundial para luchar en el bando de los Aliados contra las potencias del Eje: Alemania, Italia y Japón. De manera masiva, los hombres estadounidenses fueron llamados a filas, creando un vacío en las filas de los trabajadores, que fue llenada por las mujeres y por inmigrantes llegados del resto del hemisferio. Por cierto, una hermana de mi madre, María Julia Huguet Cañas, fue empleada para soldar planchas metálicas destinadas a dicha flota, y ella realizó ese trabajo en un lugar llamado Presidio, en la ciudad de San Francisco, California, aunque dicho lugar no era ninguna prisión.

3. Los que se pudrieron en las cárceles de Guatemala,/ México, Honduras, Nicaragual por ladrones, por contrabandistas, por estafadores,/ por hambrientos... Acá el autor enfatiza la criminalización de la pobreza, fenómeno social que tanto golpea a los emigrantes, aún ahora. Acá el verbo pudrieron tiene un claro sentido connotativo. Igual sucede en el verso siguiente: los siempre sospechosos de todo. Y a continuación cita de manera supuestamente textual una nota judicial: ("me permito remitirle al interfecto/por esquinero sospechoso/ $y$ con el agravante de ser salvadoreño"). Esta frase recalca de manera violentamente irónica la exclusión y la discriminación en razón del origen y de la nacionalidad. El término interfecto significa, según el Diccionario de la Lengua Española: "Dicho de una persona; Muerta violentamente, en especial si ha sido victima de una acción delictiva”. Esto significa que el pobre hombre en cuestión fue presuntamente muerto por la policía, o por el representante de alguna otra autoridad competente, sin que probablemente se siguiera investigación o indagatoria alguna.

4. Las que llenaron los bares y los burdeles/ de todos los puertos y las capitales de la zona. Alude acá al ejercicio de la prostitución y de la llamada "trata de blancas", de la cual han sido, y desgraciadamente todavía son, víctimas innumerables mujeres que ayer y ahora caen en las garras del crimen organizado. Y a continuación menciona los nombres, reales o supuestos, de los lupanares donde dichas mujeres son explotadas.

5. Los sembradores de maíz en plena selva extranjera. Esta es una posible alusión a las bananeras, en la costa norte de Honduras, adonde muchos salvadoreños emi-

55 Ver: https://www.panamaviejaescuela.com/gold-roll-silver-roll/, consultado el 21 de mayo de 2019. 
graron durante buena parte del siglo XX, hasta que en 1969, a raíz de una reforma agraria impulsada por el gobierno hondureño, fueron expulsados violentamente de ese país y retornados a la fuerza a El Salvador, en un incidente internacional que dio lugar a la mal llamada "Guerra del Fútbol".

6. Los reyes de la página roja. Alude a la antedicha criminalización de la pobreza, con o sin fundamento real.

7. Los que nadie sabe nadie de dónde son. Tan insignificante era hasta hace unos años El Salvador, que casi nadie sabía su ubicación geográfica. Hoy, a raíz de tantos hechos de violencia que se han suscitado en nuestro territorio nacional, esto ha comenzado a cambiar. Ahora no solo muchos ya saben, o tienen una idea aproximada, de dónde queda El Salvador, sino que empezamos, por el hecho de ser salvadoreños, a llevar cierto estigma sangriento y doloroso.

8. Los mejores artesanos del mundo. Creo que al respecto sobran los comentarios.

9. Los que fueron cosidos a balazos al cruzar la frontera. A diferencia de los mexicanos, que son cosidos a balazos "solo" al cruzar una frontera: la que divide a México de los Estados Unidos, los inmigrantes salvadoreños tienen que cruzar tres fronteras: la de El Salvador hacia Guatemala, la de este país hacia México, y la de México a los Estados Unidos. En realidad, no importa de qué frontera se trate: en todas los inmigrantes salvadoreños (y otro tanto les sucede ahora a los hondureños) no son bienvenidos.
10. Los que murieron de paludismo/ o de las picadas del escorpión o de la barba amarillal en el infierno de las bananeras. De nuevo, estos versos aluden a las difíciles condiciones de trabajo, tanto en el Canal de Panamá (paludismo), como en la costa norte de Honduras. La barba amarilla (su nombre científico es Bothropsatrox) es una de las serpientes más venenosas de América Central.

11. Los que lloraron borrachos por el bimno nacional/ bajo el ciclón del Pacífico o la nieve del norte. La nostalgia es un fenómeno común a todos los migrantes. Creo que este verso no precisa explicación.

12. Los arrimados, los mendigos, los maribuaneros,/los guanacos hijos de la gran puta... Este verso tampoco precisa mayor explicación. Sigue la enumeración de los excluidos. Guanacos es el término por el que son conocidos, coloquialmente, los salvadoreños, así como los guatemaltecos son llamados chapines, los hondureños reciben el nombre de catrachos, a los nicaragüenses se les dice chochos o nicas, y a los costarricenses, ticos.

13. Los que apenitas pudieron regresar,/ los que tuvieron un poco más de suerte,/ los eternos indocumentados... Pocos sueños y deseos son tan recurrentes, también, para los migrantes, que el del regreso. Ojalá, con éxito y con plata.

14. Los hacelotodo, los vendelotodo, los comelotodo... en estas construcciones idiomáticas, verdaderos neologismos, el autor concentra el sentido de lo que la pobreza y la exclusión obliga a hacer a los oprimidos. 
15. Los primeros en sacar el cuchillo. En general, las personas que han vivido carentes de casi todo tienen poca tolerancia a la frustración. Las respuestas violentas son aprendidas muy pronto en una sociedad que no se distingue por acoger solidariamente a nadie, mucho menos a los desposeídos.

16. Los tristes más tristes del mundo. Por esta y otras razones, nada más frecuente que una actitud desesperanzada y deprimida ante un horizonte vital que ofrece tan pocas posibilidades de alcanzar la realización personal y la felicidad. ${ }^{56}$

17. Mis compatriotas, / mis hermanos. En estos dos versos, que constituyen, como dijimos, elepifonema, encontramos una conclusión golpeante e impactante no solo porque es el cierre justo de tanta acumulación de sentido, sino porque en estas cuatro palabras el autor se identifica plenamente con aquellos que ha venido describiendo de una manera pseudodesapasionada.
Cuando Dalton asume no solo la identidad sino, sobre todo, el origen y el destino de los hombres y mujeres retratados en este poema, está planteando una opción de vida, pero también toda una ética que se convierte, en el caso de este autor, en una praxis política. Como él mismo dijo en otro poema: "Poesial Perdóname por haberte ayudado a comprender/ que no estás hecha solo de palabras". Lo cual, por no hablar, por hoy, del contenido, es una verdadera imagen poética: es claro que no fue él quien le ayudó a comprender a la poesía tal cosa, sino al revés.

O, quizás, fue la misma realidad salvadoreña, tan monstruosa y desmesurada, la que le enseñó al poeta todo: la necesidad de una praxis política que alimentaba, y se alimentaba a su vez y simultáneamente, de su praxis literaria. Para cuando el libro Las historias probibidas del Pulgarcito salió publicado, a su autor le quedaban solo unos pocos meses de vida. Y cada una de las palabras en ese libro las expresó, como todas las del resto de su obra, y las sostuvo, hasta su último respiro, con su propia vida.

56 Ver: Martín-Baró, Ignacio (1985). Acción e ideología. San Salvador, UCA Editores, segunda edición. ISBN 84-8405-051-3. El artículo, aparecido en 1973 en la revista ECA, fue publicado como un apéndice del libro. Hay versión digital: http://www.uca.edu.sv/coleccion-digital-IMB/wpcontent/uploads/2015/10/1973Psicolog\%C3\%ADadelcampesinosalvadore\%C3\%B10ECA1973-28-297_298-476_495.pdf, consultado el 15 de abril de 2019. 
AKADEMOS Enero-Junio 2020, n. ${ }^{\circ} 34$, ISSN: 1995-4743

\section{Referencias}

\section{Libros:}

1 Anderson, Thomas (2001). El Salvador, 1932. San Salvador, Dirección de Publicaciones e Impresos: Biblioteca de Historia Salvadoreña. ISBN 99923-0-049-3.

Cañas Dinarte, Carlos (2004). Diccionario de autoras y autores salvadoreños. San Salvador, Dirección de Publicaciones e Impresos. ISBN 99923-0-086-8.

3 Cardenal, Rodolfo (2015). Manual de Historia de Centroamérica. San Salvador, UCA Editores. $11^{\text {a }}$. reimpresión. ISBN 978-99923-49-01-4.

4 Carpio, Salvador Cayetano (1979). Secuestro y capucha en un país del mundo "libre". San José de Costa Rica, EDUCA. ISBN 9788483600191.

5 Dalton, Roque (2005). Miguel Mármol, los sucesos de 1932 en El Salvador. San Salvador, UCA Editores. ISBN 978-99923-34-96-6.

6 Martín-Baró, Ignacio (1985). Acción e ideología. San Salvador, UCA Editores, segunda edición. ISBN 84-8405-051-3.

7 Pineda, Roberto (2010). Las luchas populares del siglo XX en EI Salvador". En SIEP, Servicio Informativo Ecuménico y Popular. En www.ecumenico.org. Publicado el 9 de octubre de 2010 y consultado el 15 de noviembre de 2016.

8 Ribera, Ricardo. El año histórico de 1968. Diez acontecimientos que cambiaron el mundo. Versión digital: http://www.uca.edu.sv/facultad/chn/c1170/ribera6. pdf, consultada el 11 de noviembre de 2016.
9 STPP y MINEC-DIGESTYC (2015). Medición multidimensional de la pobreza. San Salvador: Secretaría Técnica y de Planificación de la Presidencia y Ministerio de Economía, a través de la Dirección General de Estadística y Censos.

10 VV AA. Proclama de la Fuerza Armada de El Salvador, 15 de octubre de 1979.

https://es.wikisource.org/wiki/Proclama_de_la_Fuerza_Armada_de_la_Rep\%C3\%BAblica_de_El_Salvador.

\section{Revistas, periódicos y sitios web:}

1 Contrapunto, periódico digital salvadoreño: PNUD: Incrementa número de salvadoreños que viven con menos de diez dólares. Pobreza en El Salvador bajó 5\% en 2013, artículo de Laura Bernal publicado el 25 de agosto de 2014.

2 Diario Oficial de El Salvador. Tomo 112, No. 28, 4 de febrero de 1932. Hay versión digital en: www.diariooficial.gob.sv/diarios/1932/1932-1T/1932-1T_Parte6. pdf, consultado el 14 de septiembre de 2016.

3 Diario Oficial de El Salvador 281, tomo 131, Decreto Legislativo número 93, del 15 de diciembre de 1941

4 Revista de la Escuela de Ciencias de la Comunicación, Universidad "Dr. José Matías Delgado", Año 8, Vol. 8, No. 1, Correlativo 15. Enero-junio 2007.

https://www.panamaviejaescuela.com/gold-roll-silver-roll/, consultado el 21 de mayo de 2019. 